\title{
HUBUNGAN STATUS GIZI DENGAN CD4 PADA PASIEN TB PARU
}

\author{
${ }^{1}$ Feby Patiung \\ ${ }^{2}$ M. C. P. Wongkar \\ ${ }^{2}$ Veny Mandang
}

\author{
${ }^{1}$ Kandidat Skripsi Fakultas Kedokteran Universitas Sam Ratulangi Manado \\ ${ }^{2}$ Bagian Ilmu Penyakit Dalam Fakultas Kedokteran Universitas Sam Ratulangi \\ Email: febypatiung@yahoo.com
}

\begin{abstract}
The background of TBC disease is well know as the main health problem for people in the world. In 1992 WHO iconed TBC as global emergency. WHO reported that 8,8 million new cases of TBC in 2002 and the rest 3,9 trilliun recorded as HIV case. Patient having TBC disease usually experience a drop in the health nutrition status or they could be categorized as having bad nutrition status. Few factors related to health nutrition of TBC patient is unefficient energy level and protein, patient's attitude towards food and health, experiencing TBC for quite a long time and the income of the patient itself. Few variables are needed to evaluate health nutrition of a TBC chronic. They are antropometrik including hematologik which are body mass index, total protein, albumin, total white blood cell, etc. The result show that there is no relation between body mass index and CD4, there is no relation between total protein and CD4, there is correlation between albumin and CD4, there is correlation between total white blood cell and CD4, and it can be concluded that health nutrition status have a high effect towards CD4.
\end{abstract}

Keywords: CD4.

\begin{abstract}
Abstrak: Latar belakang: Penyakit Tuberkulosis (TB) merupakan masalah kesehatan masyarakat utama di dunia. Pada tahun 1992 WHO telah mencanangkan tuberkulosis sebagai global emergency. Laporan WHO menyebutkan bahwa terdapat 8,8 juta kasus baru tuberkulosis pada tahun 2002 dan 3,9 juta adalah kasusHIV. Pasien TB paru seringkali mengalami penurunan status gizi, bahkan dapat menjadi status gizi buruk. Beberapa faktor yang berhubugan dengan status gizi pada pasien TB paru adalah tingkat kecukupan energi dan protein, perilaku pasien terhadap makanan dan kesehatan, lama menderita TB paru serta pendapatan perkapita pasien. Untuk menilai status gizi seseorang pasien termasuk pasien TB paru diperlukan penilaian beberapa variabel baik antropometrik maupun hematologik diantaranya : indeks masa tubuh (IMT), protein total, albumin, limfosit total dan lain-lain.

Hasil: Tidak terdapat hubungan antara IMT dengan CD4, tidak terdapat hubungan antara protein total dengan CD4, terdapat hubungan antara albumin dengan CD4, terdapat hubungan yang kuat antara limfosit totaldengan CD4, dan secara garis besar status gizi berpengaruh terhadap hasil CD4.
\end{abstract}

Kata Kunci : CD4.

Penyakit Tuberkulosis (TB) merupakan masalah kesehatan masyarakat utama di dunia. Pada tahun 1992 World Health Organization (WHO) telah mencanangkan tuberkulosis sebagai global emergency. Setiap tahunnya sekitar 4 juta penderita baru TB yang menular di dunia, ditambah dengan tidak menular. Setiap detik ada satu orang yang terinfeksi tuberkulosis di dunia ini dan sepertiga penduduk dunia telah terinfeksi kuman tuberkulosis. ${ }^{1,2}$ Laporan WHO menyebutkan bahwa terdapat 8,8 juta kasus baru tuberkulosis pada tahun 2002 dan 3,9 juta adalah kasus Human Immunodeficiency Virus(HIV) adalah masalah darurat global. ${ }^{3}$ 
Pasien TB paru seringkali mengalami penurunan status gizi, bahkan dapat menjadi status gizi buruk bila tidak diimbangi dengan diet yang tepat. Beberapa faktor yang berhubugan dengan status gizi pada pasien TB paru adalah tingkat kecukupan energi dan protein, perilaku pasien terhadap makanan dan kesehatan, lama menderita TB paru serta pendapatan perkapita pasien., Hasil penelitian menunjukkan bahwa orang dengan status gizi kurang mempunyai resiko 3,7 kali untuk menderita TB paru berat dibandingkan dengan orang yang status gizinya cukup atau lebih. Kekurangan gizi pada seseorang akan berpengaruh terhadap kekuatan daya tahan tubuh dan respon immunologik terhadap penyakit.

Untuk menilai status gizi seseorang pasien termasuk pasien TB paru diperlukan penilaian beberapa variabel baik antropometrik maupun hematologik diantaranya : indeks masa tubuh (IMT), protein total, albumin, limfosit total dan lain-lain.

Sistem pertahanan tubuh manusia turut dipengaruhi oleh status gizi seseorang, sistem pertahan tubuh yang baik bukan hanya menentukan apakah seseorang akan mudah terinfeksi tetapi juga menentukan dalam kecepatan penyembuhannya. Sistem pertahan tubuh manusia terdiri dari pertahanan spesifik dan non-spesifik. Limfosit merupakan salah satu bagian dari sistem pertahanan spesifik tingkat seluler, dimana CD4 menjadi bagian didalamnya. CD4 merupakan fraksi limfosit yang berdiferensiasi khusus yang banyak dihubungan dengan penyakit-penyakit infeksi baik akut maupun kronik termasuk TB paru. ${ }^{6}$

Penyakit infeksi dan kurangnya makan tambahan pada umumnya mempunyai hubungan dengan penyimpangan pertumbuhan dan gizi salah. Penyakit TB paru merupakan penyakit infeksi yang dapat memperburuk status gizi seseorang. ${ }^{7,8}$

\section{METODE}

Penelitian dilakukan di poliklinik paru dan instalasi rawat inap bagian Penyakit Dalam RSUP Prof. Dr. R. D. Kandou, Manado dari bulan Desember 2012 sampai bulan Januari 2013.Penelitian ini dilakukan menggunakan metode cross sectional deskriptif, prospektif, dan analitik. Populasi dalam penelitian ini adalah Pasien tuberkulosis paru di RSUP Prof. Dr. R. D. Kandou, Manado. Sebagai bahan penelitian utama ialah mengambil data yang ada di rekam medik poliklinik paru dan ruang rawat inap bagian Penyakit Dalam, anamnesis dan seleksi pasien TB paru usia dewasa dan usia lanjut. Analisis data dilakukan secara deskriptif, untuk mengetahui perbandingan status gizi dan CD4 pasien dewasa dan usia lanjut.

\section{HASIL}

\section{Data deskriptif}

\section{Distribusi sampel berdasarkan jenis kelamin}

Dari 22 sampel yang diambil di RSUP Prof. Dr. R. D. Kandou didapati 12 orang $(54,5 \%)$ perempuan dan 10 orang $(45,5 \%)$ laki-laki (Gambar 1).

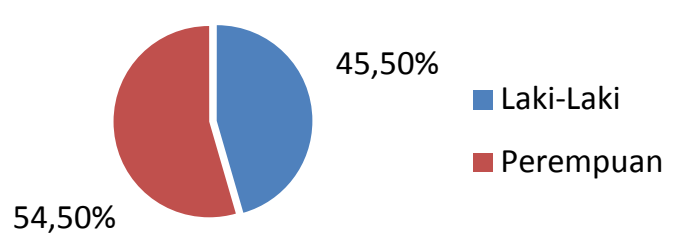

Gambar 1. Distribusi sampel berdasarkan jenis kelamin.

\section{Distribusi sampel berdasarkan kelompok umur}

Dari 22 sampel yang diambil di RSUP Prof. Dr. R. D. Kandou didapati 20 orang (90,9\%) berusia dibawah 60 tahun dan 2 orang $(9,1 \%)$ berada diusia di atas 60 tahun (Gambar 2).

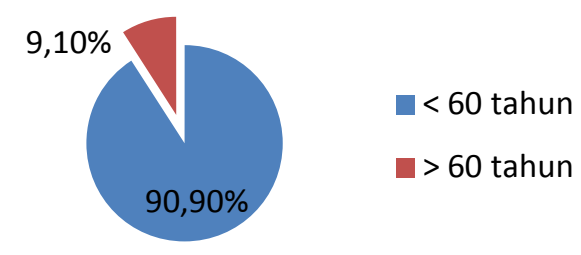

Gambar 2. Distribusi sampel berdasarkan kelompok umur. 
Patiung, Wongkar, Mandang; Hubungan Status Gizi...

\section{Distribusi sampel berdasarkan IMT}

Dari 22 sampel yang diambil di RSUP Prof. Dr. R. D. Kandou didapati hanya 4 orang $(22,2 \%)$ yang memiliki nilai IMT normal sedangkan 18 orang sisanya (77,8\%) memiliki niali IMT underweight (Gambar 3).

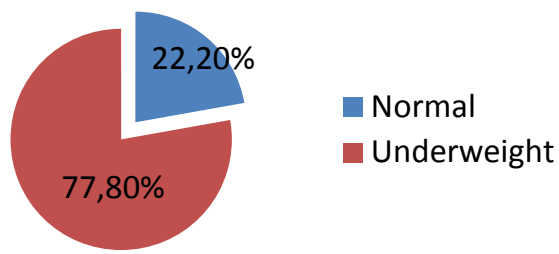

Gambar 3. Distribusi sampel berdasarkan IMT.

\section{Distribusi sampel berdasarkan protein total}

Dari 22 sampel yang diambil di RSUP Prof. Dr. R. D. Kandou didapati hanya 8 orang (36,3\%) yang memiliki hasil protein total normal sedangkan 14 orang $(63,7 \%)$ sisanya memiliki hasil protein total dibawah normal (Gambar 4).

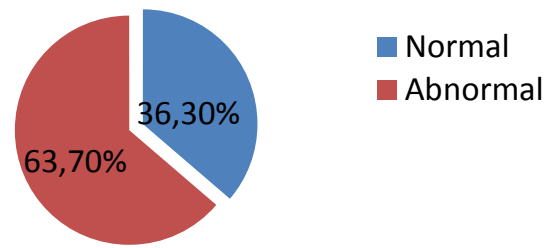

Gambar 4. Distribusi sampel berdasarkan protein total.

\section{Distribusi sampel berdasarkan albumin}

Dari 22 sampel yang diambil di RSUP Prof. Dr. R. D. Kandou didapati hanya 4 orang $(22,2 \%)$ yang memenuhi standar nilai albumin normal sedangkan 18 orang $(77,8 \%)$ tidak memenuhi standar nilai albumin normal (Gambar 5).

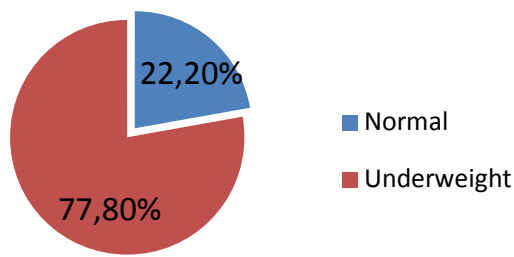

Gambar 5. Distribusi sampel berdasarkan albumin

\section{Distribusi sampel berdasarkan limfosit total}

Dari 22 sampel yang diambil di RSUP Prof. Dr. R. D. Kandou didapati 12 orang $(54,5 \%)$ yang memenuhi standar nilai limfosit total normal sedangkan 10 orang $(45,5 \%)$ tidak memenuhi standar nilai limfosit total normal (Gambar 6).

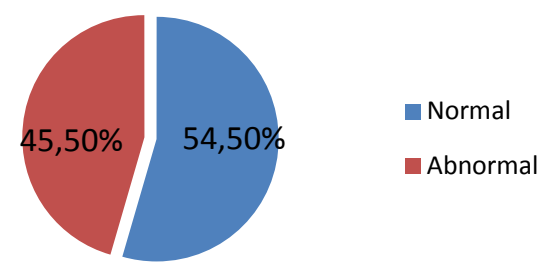

Gambar 6. Distribusi sampel berdasarkan limfosit total

\section{Distribusi sampel berdasarkan CD4}

Dari 22 sampel yang diambil di RSUP Prof. Dr. R. D. Kandou didapati 11 orang (50\%) yang memenuhi standar jumlah CD4 normal sedangkan 11 orang (50\%) tidak memenuhi standar jumlah CD4 normal (Gambar 7).

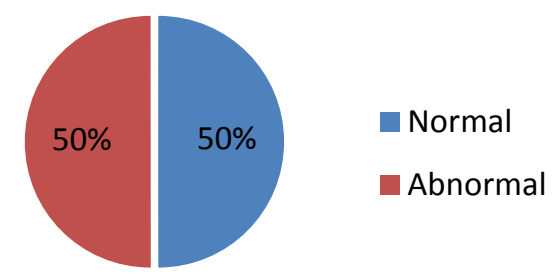

Gambar 7. Distribusi sampel berdasarkan CD4

\section{Data analitik}

\section{Hubungan IMT dengan CD4}

Hubungan IMT dengan CD4 pada penelitian ini didapatkan nilai $\mathrm{p}=0,378$ dengan nilai r=0,039 (Gambar 8).

\section{Hubungan protein total dengan CD4}

Hubungan protein total dengan CD4 pada penelitian ini didapatkan nilai $\mathrm{p}=0,194$ dan nilai $r=0,083$ (Gambar 9). 


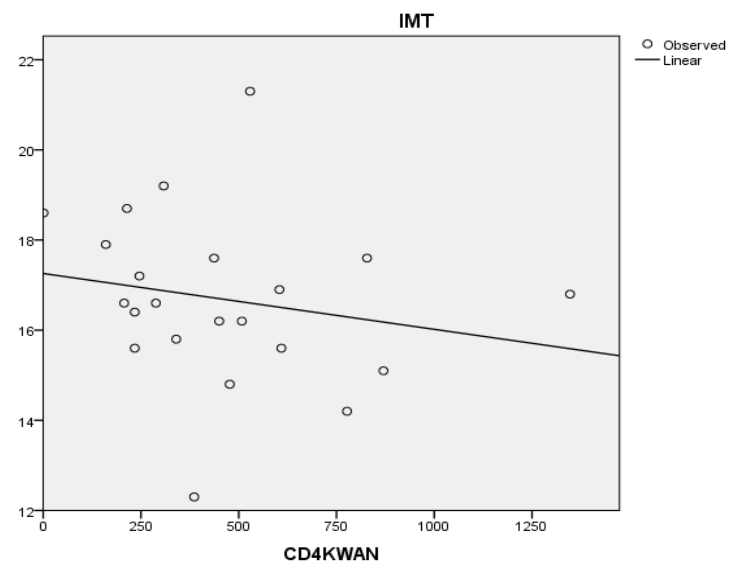

Gambar 8. Hubungan IMT dengan CD4.

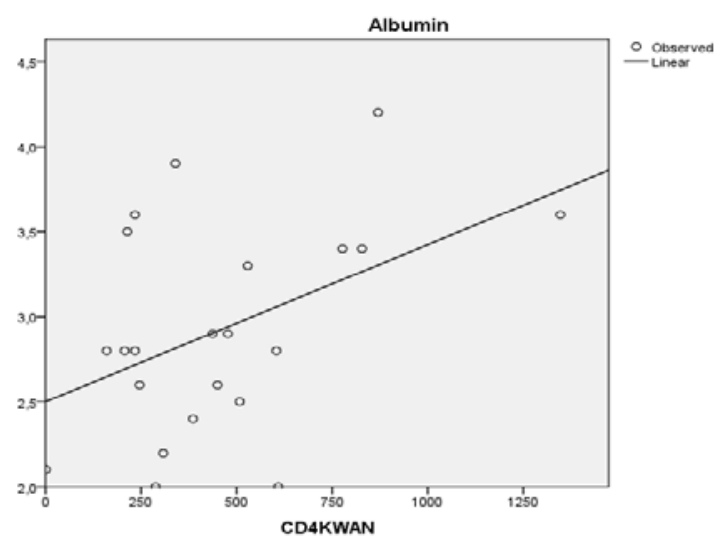

Gambar 9. Hubungan albumin dengan CD4

\section{Hubungan limfosit total dengan CD4}

Hubungan limfosit total dengan CD4 pada penelitian ini didapatkan nilai $\mathrm{p}=0,00$ dan nilai $r=0,668$ (Gambar 10).

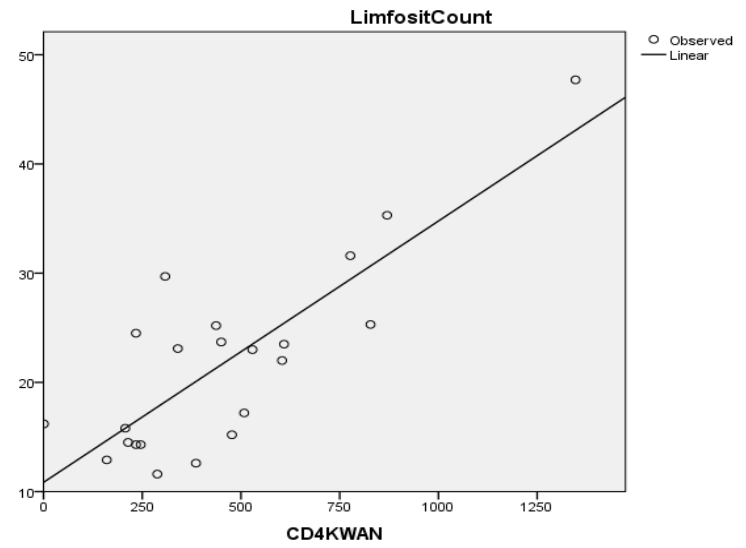

Gambar 10. Hubungan limfosit total dengan CD4.

\section{BAHASAN}

Status gizi merupakan bagian penting dalam menentukan tingkat kesehatan seseorang, status gizi disamping akan mempengaruhi sistem imun secara langsung juga berperan dalam proses penyembuhan penyakit termasuk pasien yang menderita TB paru.

Prevalensi gangguan gizi pada TB paru cukup tinggi, penelitian oleh siapa dan siapa mendapatkan prosentase gangguan gizi pada TB paru berapa persen dan berapa persen, pada penelitian kami didapatkan dari 22 sampel yang diambil terdapat sekian persen yang menderita gangguan gizibila ditinjau berdasarkan IMT 77\% menderita gizi kurang dan bila dilihat berdasarkan kadar albumin didapat $77,8 \%$ menderita gizi kurang, sedangkan bila ditinjau berdasarkan kadar protein total didapat 63,7\% menderita gizi kurang. Hal ini sesuai dengan penelitian yang akan dijelaskan di bawah ini.

Limfosit selain digunakan dalam penilaian sistem imun, juga sering digunakan sebagai salah satu parameter penilaian status gizi. Menurut penelitian yang dilakukan oleh Universitas Sumatera Utara mendapati bahwa terdapat hubungan yang berarti antara status gizi dan sistem imun dalam hal ini dengan jumlah limfosit. Dalam penelitian kami didapatkan jumlah limfosit di bawah kadar normal terdapat 45,5\%, demikian halnya dengan jumlah CD4 didapatkan 50\% jumlahnya di bawah normal. Pada penelitian ini juga terlihat bahwa terdapat hubungan yang bermakna antara albumin dengan CD4, antara limfosit total dengan $\mathrm{CD} 4$, dan antara protein total dengan CD4.

Dalam penelitian yang dilakukan di poliklinik paru dan irina C bagian Penyakit Dalam RSUP Prof. Dr. R. D. Kandou, kami mendapatkan 22 pasien yang memenuhi kriteria penelitian. Kami memulai dengan melihat data pasien tuberkulosis yaitu berat badan dan tinggi badan untuk mengetahui Indeks Massa Tubuh (IMT) lalu mengambil sampel darah dari penderita dan membawa ke laboratorium RSUP Prof. Dr. R. D. Kandou untuk diperiksa darah lengkap dan CD4 atau sistem kekebalan tubuh. 
Pemeriksaan ini hasilnya tidak sensitif dan spesifik karena pada saat tuberkulosis baru mulai (aktif) akan didapatkan jumlah leukosit yang sedikit meninggi, jumlah limfosit masih dibawah normal, laju endap darah mulai meningkat. Bila penyakit mulai sembuh, jumlah leukosit kembali normal, dan jumlah limfosit masih tinggi. ${ }^{9,10}$

Status gizi mempengaruhi kualitas kesehatan manusia. Variabel pertama yang dinilai untuk menentukan status gizi adalah IMT, dari hasil pemeriksaan dan perhitungan de Leon dkk pada tahun 2004 di Meksiko yaitu sebagian besar pasien TB memiliki status gizi dibawah normal (underweight) hal ini sesuai dengan penelitian kami didapatkan juga hasil sebagian besar $77,8 \%$ penderita memiliki status gizi underweight dan hanya 22,2\% penderita memiliki nilai IMT normal.

Variabel kedua yang dinilai dalam status gizi adalah albumin, dari hasil penelitian yang dilakukan di Universitas Muhammadiyah Semarang dan Universitas Airlangga didapatkan sebagian besar pasien memiliki nilai albumin yang rendah hal ini juga sesuai dengan penelitian kami didapatkan sebagian besar hasil albumin pasien yang 77,8\% dibawah normal dan hanya 22,2\% memiliki nilai albumin normal.

Variabel ketiga yang dinilai dalam status gizi adalah protein total, dari hasil pemeriksaan di RSPAW Salatiga Universitas Muhammadiyah Semarang yang mengatakan bahwa sebagian pesar pasien TB paru memiliki gizi buruk yang akan berpengaruh pada jumlah protein total pasien, hal ini juga sesuai dengan hasil penelitian yang kami didapati hasil Protein Total 63,7\% dibawah normal dan hanya 36,3\% yang mencapai standar protein normal.

Variabel keempat dan terakhir yang dinilai dalam status gizi adalah pemeriksaan limfosit total, dari hasil penelitian yang dilakukanoleh Nursing Academy, Government of Central Java Province didapati bahwa leukosit ringan dengan predominasi limfosit sedangkan menurut penelitian kami sekitar 45,5\% memiliki nilai yang rendah dan 54,5\% memiliki nilai dibawah normal yang tentu saja akan berpengaruh terhadap hasil pemeriksaan CD4, penulis mendapati 50\% dari penderita memiliki hasil pemeriksaan dibawah normal dan adapun 50\% sisanya memiliki hasil pemeriksaan normal dibawah yang dapat dikatakan nilai standar CD4. Karena itulah infeksi $M$. tuberculosis dapat mengundang penyakit termediasi HIV, mungkin lewat perangsangan replikasi virus pada penderita tuberkulosis dengan kekebalan tubuh rendah. ${ }^{11-13}$

Dan untuk melihat hubungan status gizi dengan CD4, penulis antara IMT, Protein Total, Albumin, Limfosit Total dengan CD4. Kurva pertama yang akan dinilai adalah kurva IMT dengan CD4, menurut penelitian yang dilakukan oleh Dr. Vivekanand Jha di India didapatkan hasil $\mathrm{p}<0,0001$ dan $\mathrm{r}=0,505$ pada penelitian kami didapatkan nilai $\mathrm{p}=0,378$ dan $\mathrm{r}=0,039$ (tidak signifikan).

Berikut yang dinilai adalalah kurva hubungan antara protein total dengan CD4, menurut hasil penelitian US National Library of Medicine didapati $\mathrm{p}<0,01$ dan $r=0,35$ sedangkan hasil yang didapati oleh penulis adalah $\mathrm{p}=0,194$ dan $\mathrm{r}=0,083$ dapat dilihat disini bahwa protein total tidak memiliki hubungan yang signifikan terhadap jumlah CD4.

Kurva berikut adalah kurva hubungan antara albumin dengan CD4, menurut hasil penelitian Olawuni $\mathrm{HO}$ dalam health monitoring didapati $\mathrm{p}=0,006$ dan $\mathrm{r}=0,231$ hal ini sesuai dengan penelitian yang dilakukan oleh penulis didapati nilai $\mathrm{p}=0,037$ dan $\mathrm{r}=0,200$. Dari hasil penelitian dapat dilihat hubungan yang signifikan jadi dapat dikatakan albumin mempengaruhi jumlah CD4.

Yang terakhir adalah kurva hubungan antara limfosit total dengan CD4, menurut hasil penelitian dari Universitas Sumatera Utara didapatkan hasil $\mathrm{p}<0,01$ dan $\mathrm{r}=0,55$ dan ini sesuai dengan hasil penelitian kami didapatkan nilai $\mathrm{p}=0,00$ dan $\mathrm{r}=0,668$. Dari hasil penelitian itu berarti dapat dikatakan bahwa adanya hubungan yang bermakna antara limfosit total dengan CD4 hak itu ditunjukkan dengan garis tegak pada kurva. 
Untuk itu penderita TB paru harus diberikan terapi diet seperti memberikan makanan secukupnyauntuk memenuhi kebutuhan zatgizi yang bertambah guna mencegah atau mengurangikerusakan jaringan tubuh. Prinsip yang diberikan energi yang tinggi (2500-3000 kal/hari) untuk mencapai berat badan ideal, protein tinggi (75-100 gram/hari) untuk menggantikan sel-sel yang rusak dan meningkatkan kadar serum, suplementasi vitamin yang tinggi seperti vitamin $\mathrm{C}$, vitamin $\mathrm{E}$, vitamin B kompleks dan mineral yang cukup, serta makanan yg mudah dicerna. ${ }^{14-16}$

\section{SIMPULAN}

Berdasarkan penelitian yang dilakukan telah didapatkan hasil bahwa tidak terdapat hubungan antara IMT dengan CD4, tidak terdapat hubungan antara protein total dengan CD4, terdapat hubungan antara albumin dengan CD4, terdapat hubungan yang kuat antara limfosit totaldengan CD4dan secara garis besar status gizi berpengaruh terhadap hasil CD4.

\section{SARAN}

Perlu diperhatikan status gizi pada pasien TB karena kebanyakan pasien TB memiliki gizi buruk yang akan berpengaruh pada sistem kekebalan tubuh. Serta perlu juga diperhatikan pola makan dan asupan nutrisi pada pasien TB agar memiliki status gizi yang baik.

\section{UCAPAN TERIMA KASIH}

Kepada penguji 1 dan penguji 2 yang telah banyak memberikan masukan dan perbaikan terhadap penulisan skripsi ini dan juga kepada semua pihak yang secara langsung dan tidak langsung yang telah membantu hingga jurnal ini dapat dibuat.

\section{DAFTAR PUSTAKA}

1. World Health Organization. Guidelines for establishing DOTS-Plus pilot projects for the management of multidrug-resistant tuberculosis. Geneva: WHO; 2000
2. Aditama TY, Soepandi PZ. Tuberkulosis, terapi dan masalahnya (Edisi ke-3). Jakarta: Lab. Mikrobiologi RSUP Persahabatan/WHO Collaborating Center for Tuberculosis; 2000.p.31-47.

3. World Health Organization. Treatment of tuberculosis. Guidelines for national programmes. Geneva: WHO;1993.

4. World Health Organization. Global tuberculosis programme: Global tuberculosis control. WHO report; 2013.

5. Dye, Scheele S, Dolin P, Pathana V, Raviglione MC. Global burden of tuberculosis. Estimated incidence and mortality by country. JAMA 1999;282:67786.

6. Soeparman, Sarwono W. Ilmu Penyakit Dalam Jilid II Edisi I. Jakarta: Gaya Baru; 1991. Hal: 3-6

7. Aditama TY. MOTT dan MDR. J Respir Indo. 2004;24:157-9.

8. World Health Organization. Definition of elderly. WHO/HTM/DE/2011. Geneva, Switzerland: WHO; 2009.

9. Amin, Zulkifli. Manifestasi Klinik dan Pendekatan Pada Pasien Dengan Kelainan Sistem Pernapasan. Dalam: Sudoyo, Aru W. Setiyohadi, Bambang. Alwi, Idrus. Simadibrata K, Marcellus. Setiati, Siti. Buku Ajar Ilmu Penyakit Dalam Jilid II (Edisi ke4). Jakarta: Pusat Penerbitan Departemen Ilmu Penyakit Dalam FKUI; 2007.

10. Amin, Zulkifli. Bahar, Asril. Tuberkulosis Paru. Dalam: Sudoyo, Aru W. Setiyohadi, Bambang. Alwi, Idrus. Simadibrata K, Marcellus. Setiati, Siti. Buku Ajar Ilmu Penyakit Dalam Jilid II (Edisi ke-4). Jakarta: Pusat Penerbitan Departemen Ilmu Penyakit Dalam FKUI; 2007.

11. Maria Grazia Garrino, Youri Glupczynski, Josiane Degraux, Henri Nizet, And Michel Delme'E. Evaluation of the Abbott LCx Mycobacterium tuberculosis Assay for Direct Detection of Mycobacterium tuberculosis Complex in Human Samples. J. Clin. Microbiol Jan. 1999, p.229-32.

12. Bloom BR, Murray CJ. Tuberculosis: commentary on a reemergent killer. Science. 1992 Aug 21;257(5073):1055-64.

13. Guerrero A, Cono J, Fortun J, Navas E, Quereda C, Ascensio A, et al. Nosocomial transmission of Mycobacterium bovis resistant to 11 drugs in people with advanced HIV-1 infection. Lancet. 1997;350:1738-42. 
Patiung, Wongkar, Mandang; Hubungan Status Gizi...

14. Departemen Kesehatan Republik Indonesia. Pedoman Nasional Penanggulangan Tuberkulosis (Edisi ke-2) Cetakan Pertama. Jakarta: Depkes RI; 2007.

15. Price, Sylvia A. Standridge, Mary $P$. Tuberkulosis Paru. Dalam: Price, Sylvia A. Wilson, Lorraine, eds. Patofisiologi: Konsep Klinis Proses-Proses Penyakit Volume 2 (Edisi 6). Jakarta: EGC; 2006.
16. Rahmatullah, Pasiyan. Bronkiektasis. Dalam: Sudoyo, Aru W. Setiyohadi, Bambang. Alwi, Idrus. Simadibrata K, Marcellus. Setiati, Siti. Buku Ajar Ilmu Penyakit Dalam Jilid II (Edisi IV). Jakarta: Pusat Penerbitan Departemen Ilmu Penyakit Dalam FKUI; 2007. 